\title{
Cross-Border Marriages
}


This page intentionally left blank 


\section{Cross-Border Marriages}

Gender and Mobility in Transnational Asia

Edited by

Nicole Constable

\section{PENN}

University of Pennsylvania Press

Philadelphia 
Copyright 02005 University of Pennsylvania Press

All rights reserved

Printed in the Lnited States of America on acid-free paper

$\begin{array}{llllllllll}10 & 9 & 8 & 7 & 6 & 5 & 4 & 3 & 2 & 1\end{array}$

Published by

University of Pennsylvania Press

Philadelphia, Pennsylvania 19104-4011

Library of Congress Cataloging-in-Publication Data

Cross-border marriages : gender and mobility in transnational Asia / edited by Nicole Constable.

p. $\mathrm{cm}$

Includes bibliographical references and index.

ISBN 0-8122-3830-3 (cloth : alk. paper) - ISBN 0-8122-1891-4 (paper : alk. paper)

1. Intercountry marriage. 2. Intercountry marriage-Asia. 3. Social

mobility. 4. Asian women--Foreign countries. I. Constable, Nicole.

HQ1032.C67 2005

$306.84^{\prime} 5^{\prime} 095 \mathrm{dc} 22$ 